\title{
ESTIMADO FERNANDO
}

\author{
ELZA BERQUÓ
}

Há quarenta e três anos, três meses, treze dias e uma hora (3 de maio de 1969, às 17 horas) nos encontrávamos no apartamento 122 da rua Espírito Santo, do saudoso Candido Procópio Ferreira de Camargo, para fundaro Cebrap como uma sociedade civil, sem fins lucrativos, com objetivos de pesquisa, assistência técnica, consultoria, treinamento e ensino.

Essa iniciativa se deu sob sua inspiração e liderança.

Afastados da USP pelo AI-5, de 13 de dezembro de 1968 , em menos de seis meses já estávamos unidos em torno de um projeto comum, que permitiu que nos apoiássemos uns aos outros naqueles anos da truculenta ditadura militar.

Todos nós tivemos oportunidades de deixar o país, a convite de universidades estrangeiras, mas decidimos ficar para dar continuidade aos nossos estudos de pensar o Brasil na perspectiva da retomada de seu destino democrático. E conseguimos.

Você foi o que chegou mais longe, embora sempre perto dos fundadores, dos amigos e das novas gerações do Cebrap.

Ao entregar a ata da fundação do Cebrap, entrego o registro de um pedaço de nossa história.

Parabéns!

ELZA BERQUó é professora titular da Faculdade de Saúde Pública da Universidade de São Paulo e fundadora do Cebrap. 